\title{
Olive Leaves and Mill Waste Exert Anti-Tumoral Properties in Hepatoma Cell Line
}

\author{
Isidora Ranchal ${ }^{1}$ María D Luque de Castro ${ }^{2}$ and Jordi Muntané ${ }^{1-4 *}$ \\ ${ }^{1}$ Unit for the Clinical Management of Digestive Diseases and CIBERehd, Hospital Universitario de Valme, Sevilla, Spain \\ ${ }^{2}$ Department of Analytical Chemistry, IMIBIC (Instituto Maimónides para la Investigación Biomédica de Córdoba), University of Córdoba, Córdoba, Spain \\ ${ }^{3}$ Department of General Surgery, Hospital Universitario Virgen del Rocio/IBiS/CSIC/Universidad de Sevilla, Seville, Spain \\ ${ }^{4}$ Centro de Investigación Biomédica en Red de Enfermedades Hepáticas y Digestivas (CIBERehd), Barcelona, Spain
}

*Corresponding author: Jordi Muntané, Instituto de Biomedicina de Sevilla, Hospital Universitario Virgen del Rocío, Av. Manuel Siurot s/n, 410013 Sevilla, Spain, Tel: +34 955923122; Fax: +34 955923101; E-mail: jmuntane-ibis@us.es

Received date: Mar 11, 2014; Accepted date: Apr 26, 2014; Published date: May 07, 2014

Copyright: (c) 2014 Ranchal I, et al. This is an open-access article distributed under the terms of the Creative Commons Attribution License, which permits unrestricted use, distribution, and reproduction in any medium, provided the original author and source are credited.

\begin{abstract}
Different phenolic compounds such as oleuropein and hydroxytyrosol have demonstrated antitumoral activity in cancer cell lines. Olive derivatives have demonstrated beneficial properties in cardiovascular diseases. The study was addressed to show the potential beneficial properties of olive leaves and olive oil mill waste extracts in hepatoma cell lines. Aflatoxin B1 (AFB1) was administered to hepatoma cell line (HepG2). Different parameters related to cell death, cell proliferation and DNA damage were determined. The expression of p53 and c-Src (activated and inhibitory phosphorylated state) was assessed by Western blot analysis in HepG2. The olive leaves and olive oil mill waste extracts contained oleuropein and hydroxytyrosol, respectively. AFB1 induced cell proliferation and death, associated to a rise on p53 and c-Src expression in HepG2 cells. Oleuropein and hydroxytyrosol reduced cell necrosis and DNA damage in HepG2 cells. However, the administration of olive leaves and olive oil mill waste extracts increased cell necrosis, DNA damage. These effects of natural extracts were associated with a reduction of activated c-Src expression and cell proliferation in AFB1-treated HepG2 cells. These results support that olive leaves extract and olive oil mill waste extracts, but not oleuropein and hydroxytyrosol, may exert antitumoral effect against a hepatoma cancer cell line.
\end{abstract}

Keywords: Olive leaf extract; Oleuropein; Olive oil mill waste; Hydroxytyrosol; DNA damage; Cell death

\section{Abbreviations:}

HCC: Hepatocellular Carcinoma; AFB1: Aflatoxin B1; CDK: Cyclin-Dependent Protein Kinases; Hepg2: Human Hepatoma Cell Line; DMSO: Dimethyl Sufoxide; EDTA: Ethylene Diamine Tetra Acetic Acid; FBS: Fetal Bovine Serum; PBS: Phosphate-Buffered Saline; PMSF: Phenylmethyl Sulfonylfluoride; Rnase: Ribonuclease; SDSPAGE: Sodium Dodecyl Sulfate-Polyacrylamide Gel; TBS: Tris Buffered Saline

\section{Introduction}

Hepatocellular carcinoma (HCC) is the third leading cause of cancer deaths worldwide, and accounts for an overall incidence of 560,000 new cases per year [1,2]. In the era of molecularly targeted, rationally designed cancer therapeutics, natural environment, and especially plants continue to provide a rich source of anticancer agents.

The Mediterranean diet, characterized by an abundance of fruits and vegetables, contributes to the prevention of various chronic degenerative diseases such as cardiovascular diseases and cancer [3]. Case-control, cohort, and prospective epidemiological studies have generated conflicting results regarding a protective effect of an olive oil-rich Mediterranean diet against several malignancies, especially breast cancer [4-8]. Olive tree (Olea Europaea) products are essential elements of Mediterranean diet. Olive oil is the major fat source of this diet and is considered an important component responsible, at least in part, for the low incidence of cardiovascular diseases in the Mediterranean area [9]. The beneficial health effects of olive oil have been mainly attributed to the high content of the mono-unsaturated fatty acid oleic acid, while less attention has been given to other minor constituents such as phenolic antioxidant [10] present in appreciable amounts in crude olive oil $(50-900 \mathrm{mg} / \mathrm{kg})$ [11-13]. The phenolic compounds of olive oil and leaf are a complex mixture of compounds that include 3,4-dihydroxyphenylethanol (hydroxytyrosol), 4hydroxyphenylethanol (tyrosol), 4-hydroxyphenylacetic acid, protocatechuic acid, caffeic acid and p-coumaric acid, among others $[14,15]$. The concentration of the phenolic fraction is several times higher in olive leaf than in oil. Apart from studies focused in olive oil composition, other studies have considered the constituents present in olive leaf extracts and olive oil mill waste (named "alperujo") extracts mainly because of the availability and low cost of raw material in the region of Mediterranean.

Hydroxytyrosol (3,4-dihydroxyphenylethanol; DOPET) is the main ortho-diphenolic compound found in olive oil and responsible for its antioxidant properties [16,17]. Among the antioxidants in olive oil, hydroxytyrosol or 2-(3,4-dihydroxyphenyl)ethanol (DPE) has a remarkable protective effect against oxidative stress-related damage. It has been shown to prevent low-density lipoprotein oxidation [18] and platelet aggregation [19]. Oleuropein is the most abundant of the phenolic compounds in olives [20]. It actively scavenges reactive 
oxygen [21] and nitrogen species [22], with anti-angiogenic activity [23].

Both hydroxytyrosol and oleuropein have been shown to possess anti-inflammatory, bactericidal and bacteriostatic activities [24]. Some in vivo studies on olive leaf have shown that its extract can decrease blood pressure and dilate the coronary arteries surrounding the heart [25]. Moreover, hydroxytyrosol has been shown to have anti-cancer effect on human colon adenocarcinoma HT-29 cells and human promyelocytic leukemia HL-60 cells $[26,27]$ have anti-melanogenesis activity, whereas oleuropein inhibited cell growth of LN-18, poorly differentiated glioblastoma; TF-1a, erythroleukemia; 786-O, renal cell adenocarcinoma; T-47D, infiltrating ductal carcinoma of the breastpleural effusion; RPMI-7951, malignant melanoma of the skinlymph node metastasis; and LoVo, colorectal adenocarcinoma cells [28]. Even though anticancer properties of oleuropein and hydroxytyrosol were confirmed in vitro with different cell lines, studies of their protective effect from liver cancer have not been demonstrated.

Aflatoxin B1 (AFB1) is naturally occurring mycotoxins elaborated by Aspergillus flavus and Aspergillus parasiticus that grow readily on foodstuffs stored in damp conditions like mouldy rice, hundredth wheat, barley, etc. The adverse health effects associated with AFB1 exposure range from acute liver toxicities to liver cancer in humans [29]. AFB1-exo-8, 9-epoxide metabolized by hepatic cytochrome P450-family member, CYP1A2 and CYP3A4, which has been shown to bind and damage DNA [30]. Different reports have showed that a G to $\mathrm{T}$ transversion of the third nucleotide in codon 249 of the p53 gene (249ser) [31-33], and Ras and Myc activation [34] are associated with AFB1-induced HCC.

Neoplastic progression of cancer cells is associated with chromosome damage that allows cells to escape from growth and proliferation controls and disables apoptosis. In these conditions, cell cycle progression is tightly regulated allowing arrest and repair of damaged DNA. The cell cycle is regulated through the sequential activation and inactivation of cyclin-dependent protein kinases (CDK) that control specific steps of the cycle progression, such as G1-S and G2-M transitions. CDK activation requires the binding to different cyclins (A, B, E, and D), which are timely expressed during the course of the cell cycle [35]. CDK activity is also regulated by a diverse family of proteins termed CDK inhibitors (CKDi) that bind and inactivate $\mathrm{CDK}$-cyclin complexes. There is a general agreement that the control of differentiation is tightly coupled to proliferation and some important molecules involved in the control of cell cycle progression, such as CIP/KIP family members named p21WAF1/Cip1 and p27Kip1, which are also implicated in the regulation of differentiation and apoptosis [36]. The expression of p53 is important for cell proliferation and death $[24,37]$. The human SRC gene encodes pp60cSrc, a $60-\mathrm{kDa}$ non-receptor, membrane-associated tyrosine kinase. CSrc was first identified based on homology to $\mathrm{v}$-Src, the potent transforming oncogene encoded in the Rous Sarcoma Virus (RSV) genome [38]. It is thought that c-Src cooperates with activated and/or overexpressed receptor tyrosine kinases (RTKs) in many human cancers where c-Src activation has been reported [39,40]. c-Src overexpression has been documented in upwards of $50 \%$ of human tumors derived from colon, liver, breast, lung, and pancreas [41-46].

The aim of the study was the identification of anticancer properties of olive leaves extract and olive oil mill waste extracts in control and pro-carcinogenic Aflatoxin B1-treated hepatoma cells. In addition, we evaluated if their most abundant compound such as oleuropein in olive leaves and hydroxytyrosol in olive mill waste extracts affect cell death in hepatoma cells. The study showed that the administration of natural extracts was to increase DNA damage, cell cycle arrest and apoptosis in hepatoma cell lines.

\section{Material and Methods}

\section{Material, reagents and standards}

The olive leaves were collected, washed, dried in open air, and stored in freeze. The humidity content of olive oil mill waste or "alperujo" was eliminated by drying at $35^{\circ} \mathrm{C}$ for $24 \mathrm{~h}$ and stored at $-20^{\circ} \mathrm{C}$. Oleuropein and hydroxytyrosol were obtained from Extrasynthese (Genay, France).

\section{Extraction procedures}

The olive phenols from leaves were submitted to microwaveassisted extraction (MAE) with ethanol-water according to previously described procedure $[47,48]$. The irradiation power was set at $200 \mathrm{~W}$ with $80: 20(\mathrm{v} / \mathrm{v})$ ethanol-water during 8 minutes. The superheated liquid extraction has been demonstrated to provide quantitative extraction of the target phenols of "alperujo" [47,48]. Thus, a staticdynamic method using 80:20 (v/v) ethanol-water at $200^{\circ} \mathrm{C}$ was used for sample preparation. The extraction time was $12 \mathrm{~min}$ for the static step and $15 \mathrm{~min}$ for the dynamic one using $1 \mathrm{~mL} / \mathrm{min}$ extracting flowrate.

\section{Cell Lines and culture conditions}

Human hepatoma cell line (HepG2) was obtained from the ECACC (European Collection of Cell Cultures) and routinely maintained in MEM medium $\mathrm{pH} 7.4$ supplemented with $10 \%$ fetal bovine serum, 2.2 $\mathrm{g} / \mathrm{L} \mathrm{HCO} 3 \mathrm{Na}, 100 \mathrm{mM}$ sodium pyruvate, $0.292 \mathrm{gr} / \mathrm{L}$ glutamine, 100 $\mathrm{U} / \mathrm{mL}$ penicillin, $100 \mu \mathrm{g} / \mathrm{mL}$ streptomycin and $0.25 \mu \mathrm{g} / \mathrm{mL}$ amphotericin in $5 \% \mathrm{CO} 2$ in air at $37^{\circ} \mathrm{C}$. The study was initiated 24 hours after seeding in fresh culture medium. It was carried out a kinetic study of citotoxicity with AFB1 $(50 \mu \mathrm{g} / \mathrm{mL})$ dissolved in DMSO. Oleuropein $(0.5,0.05,0.005 \mathrm{mg} / \mathrm{mL}$ ), olive leaf extract (at a $0.5,0.05,0.005 \mathrm{mg} / \mathrm{mL}$ in relation to oleuropein concentration), hydroxytyrosol $(0.05,0.005,0.0005 \mathrm{mg} / \mathrm{mL})$, and "alperujo" (0.05, $0.005,0.0005 \mathrm{mg} / \mathrm{mL}$ in relation to hydroxytyrosol concentration). Compounds were co-administered with AFB1. Samples were collected 0,12 and $24 \mathrm{~h}$ after the addition of compounds. The final concentration of DMSO $(0.005 \% \mathrm{v} / \mathrm{v})$ had no effect on experimental parameters.

\section{Preparation of cytoplasmic and nuclear extracts}

Nuclear extracts from hepatocytes were prepared according to Schreiber et al. [49]. Briefly, hepatocytes were recovered in $200 \mu \mathrm{l}$ of lysis buffer (10 mM HEPES pH 7.9, $10 \mathrm{mM} \mathrm{KCl}, 0.1 \mathrm{mM}$ EDTA, 0.1 mM EGTA, $5 \mu \mathrm{g} / \mathrm{ml}$ aprotinin, $10 \mu \mathrm{g} / \mathrm{ml}$ leupeptin, $0.5 \mathrm{mM}$ phenyl methyl sulfonyl fluoride, $1 \mathrm{mM}$ DTT,0.6\% Nonidet NP-40) allowing to swell for $10 \mathrm{~min}$ on ice. Afterwards, samples were homogenized and centrifuged at $15,000 \mathrm{x} \mathrm{g}$ for $1 \mathrm{~min}$ at $4{ }^{\circ} \mathrm{C}$. After removal the supernatant (cytoplasmic fraction), the nuclear pellet was resuspended in $25 \mu \mathrm{L}$ of nuclear extraction buffer (20 mM HEPES pH 7.9, $0.4 \mathrm{mM}$ $\mathrm{NaCl}, 1 \mathrm{mM}$ EDTA, $1 \mathrm{mM}$ EGTA, $5 \mu \mathrm{g} / \mathrm{mL}$ aprotinin, $10 \mu \mathrm{g} / \mathrm{mL}$ leupeptin, $0.5 \mathrm{mM}$ phenyl methyl sulfonyl fluoride, and $1 \mathrm{mM}$ DTT). The tube was incubated for $20 \mathrm{~min}$ on ice with continuous mixing and 
centrifuged at $15,000 \mathrm{xg}$ for $5 \mathrm{~min}$ at $4^{\circ} \mathrm{C}$. Aliquots of the supernatant (nuclear fraction) were stored at $-80^{\circ} \mathrm{C}$ until use.

\section{Measurement of lactate dehydrogenase release}

Lactate dehydrogenase (LDH) in the culture medium was measured by modification of a colorimetric routine laboratory method [50]. Briefly, a volume of medium or cytoplasmic fraction ranging from 5-125 $\mu \mathrm{L}$ was incubated with $0.2 \mathrm{mM} \beta-\mathrm{NADH}$ and $0.4 \mathrm{mM}$ pyruvic acid diluted in $100 \mathrm{mM}$ PBS pH 7.4. LDH concentration in the sample was proportional to the linear decrease in the absorbance at $334 \mathrm{~nm}$ and calculated using a commercial standard. LDH release represents the percentage of $\mathrm{LDH}$ in culture medium in relation to the total $\mathrm{LDH}$ (culture medium and cell lysate).

\section{Assay for caspase-3-associated activity}

The cytoplasmic fractions obtained above were also used to measure caspase- 3 activity in cultured hepatocytes. The enzymatic activity in the cell extract $(15 \mu \mathrm{g})$ was measured using the corresponding peptide-based substrate (Ac-DEVD-AFC, $100 \mu \mathrm{M}$ ) in caspase-incubating buffer (50 mM HEPES pH 7.5, $100 \mathrm{mM} \mathrm{NaCl}, 10 \%$ sucrose, $0.1 \%$ CHAPS, $1 \mathrm{mM}$ EDTA and $5 \mathrm{mM}$ DTT) up to $100 \mu \mathrm{L}$ total volume. The increase in fluorescence of the sample of enzymatically released AFC measured at Ex $400 \mathrm{~nm}$ and Em $505 \mathrm{~nm}$ was recorded using a GENios Reader (TECAN, Salzburg, Austria).

Analysis of c-Src Total, Phospho-Src (Tyr527), Phospo-Src (Tyr416), p21, p27, Wild and Mutated p53 Expression by WesternBlot in HepG2

The cytoplasmic and nuclear fractions obtained above were used to measure c-Src total, phospho-Src (Tyr527) and phospo-Src (Tyr416), as well as p21Waf1/Cip, p27Kip1, native and mutated p53 protein expression in cultured HepG2 cells, respectively. Proteins $(20-100 \mu \mathrm{g})$ were separated by $10-14 \%$ SDS-PAGE electrophoresis and transferred to nitrocellulose for Western-blot analysis using anti-c-Src (2109, Cell Signalling Technology, Inc), phospho-Src (Tyr527) (2105, Cell Signalling Technology, Inc), phospho-Src (Tyr416) (2101, Cell Signaling Technology, Inc), p27Kip1 (sc-528, Santa Cruz Biotechnology), p21Cip1 (sc-397, Santa Cruz Biotechnology), wild type p53 (sc-6243, Santa Cruz Biotechnology) and mutated p53 (sc-91, Santa Cruz Biotechnology) primary antibodies. Samples were incubated with the corresponding secondary antibodies. The sample was incubated with horseradish peroxidase.

\section{Cell proliferation-assay}

Cell proliferation was determined by BrdU (5-bromo-2'deoxyuridine)-ELISA based assay (Roche Applied Science, Mannheim, Germany) according to the manufacturer's instructions. Briefly, BrdU $(10 \mu \mathrm{M})$ was added $4 \mathrm{~h}$ before collecting samples, washed with $10 \%$ SFB containing medium, and fixed with $200 \mu \mathrm{L}$ of precooled commercial fixative solution during $30 \mathrm{~min}$ at $-20^{\circ} \mathrm{C}$. Cells were treated with nuclease for $30 \mathrm{~min}$ at $37^{\circ} \mathrm{C}$, and incubated with antiBrdU-POD for $30 \mathrm{~min}$ at $37^{\circ} \mathrm{C}$. The BrdU incorporation was measured at 405/492 nm (Tecan, Spectrofluor, Salburg Astria).

\section{Detection of 8-Hydroxydeoxiguanosine formation in hepatocytes}

Cells were cultured onto glass bottom culture dishes coated with collagen (MatTek Corporation, Ashland, MA, USA). Cells were fixed with cold $70 \%$ ethanol for 10 minutes, and incubated with $100 \mu \mathrm{g} / \mathrm{mL}$ RNAse diluted in $10 \mathrm{mM}$ Tris- $\mathrm{HCl}, 1 \mathrm{mM}$ EDTA and $0.4 \mathrm{mM} \mathrm{NaCl}$ pH 7.5 at $37^{\circ} \mathrm{C}$ for 1 hour. After cell washing with PBS, DNA was denatured by soaking the slides in $50 \mathrm{mM}$ Tris-base at room temperature for 5 minutes, and reduced unspecific binding with $10 \%$ $\mathrm{SBF}$ in $10 \mathrm{mM}$ Tris- $\mathrm{HCl} \mathrm{pH} 7.5$ and at $37^{\circ} \mathrm{C}$ for 1 hour. Samples were incubated with goat polyclonal anti-8-hydroxydeoxiguanosine antibodies (Chemicon International) (1:300) in 10\% fetal bovine serum at $4{ }^{\circ} \mathrm{C}$ overnight. Biotin anti-goat Ig $\mathrm{G}(\mathrm{H}+\mathrm{L})$ polyclonal antibodies (Jackson Immuno-Research Laboratories, West Grove, PA, USA) diluted (1:500) in $10 \%$ fetal bovine serum and $10 \mathrm{mM}$ Tris- $\mathrm{HCl}$ $\mathrm{pH} 7.5$ at $37^{\circ} \mathrm{C}$ for 30 minutes. At this point, slides were treated with $\mathrm{H} 2 \mathrm{O} 2$ (3\%) in methanol at room temperature for 30 minutes in order to avoid DNA damage before immunological detection. Samples were incubated with streptavidin-horseradish peroxidase for $30 \mathrm{~min}$, washed twice with $1 \%$ Triton X-100, and incubated with in DAB and $\mathrm{H} 2 \mathrm{O} 2(0.001 \%)$ for $10 \mathrm{~min}$. Slides were washed with deionised water and counterstained with $1 \%$ methyl green for $2 \mathrm{~min}$. The samples were washed, dehydrated in $95 \%$ and $100 \%$ ethanol, clarified by xylene and mounted with Eukkit ${ }^{\star}$ mounting media. Apoptotic index was determined by counting the percentage of positive cells in 200 cells.

\section{Statistical analysis}

Data were expressed as Mean \pm SE of five experiments. Data were compared using ANOVA with the Least Significant Difference (LSD) test as post-hoc multiple comparison analysis. The statistical differences were set at $\mathrm{p} \leq 0.05$. The groups with " $a$ " were significantly different vs. the corresponding control group. The groups with "b" were significantly different vs. the corresponding group without AFB1. The images or blots are representative of five independent experiments.

\begin{tabular}{|l|l|l|}
\hline & Phenolic compounds & $(\mathrm{mg} / 1)$ \\
\hline \multirow{3}{*}{ Olive leaves } & Oleuropein & 3427.0 \\
\cline { 2 - 3 } & Apigenin-7-glucoside & 35.1 \\
\cline { 2 - 3 } & Verbascoside & 30.2 \\
\cline { 2 - 3 } & Luteolin & 32.0 \\
\cline { 2 - 3 } & Apigenin & 13.0 \\
\hline \multirow{2}{*}{$\begin{array}{l}\text { Olive oil mil } \\
\text { waste }\end{array}$} & Hydroxytyrosol & 15.2 \\
\hline
\end{tabular}

Table 1: Phenolic compounds present in olive leaves and olive oil mill waste extracts.

\section{Results}

The analysis of olive leaves extract and olive oil mill waste showed that oleuropein hydroxytyrosol (3,4 DHPEAEDA) were the most abundant compound, respectively. The concentrations of polyphenols $(\mathrm{mg} / \mathrm{L})$ detected in olive leaf and oil mill wastes are shown in Table 1. 
Citation: Ranchal I, de Castro ML, Muntané J (2014) Olive Leaves and Mill Waste Exert Anti-Tumoral Properties in Hepatoma Cell Line. J
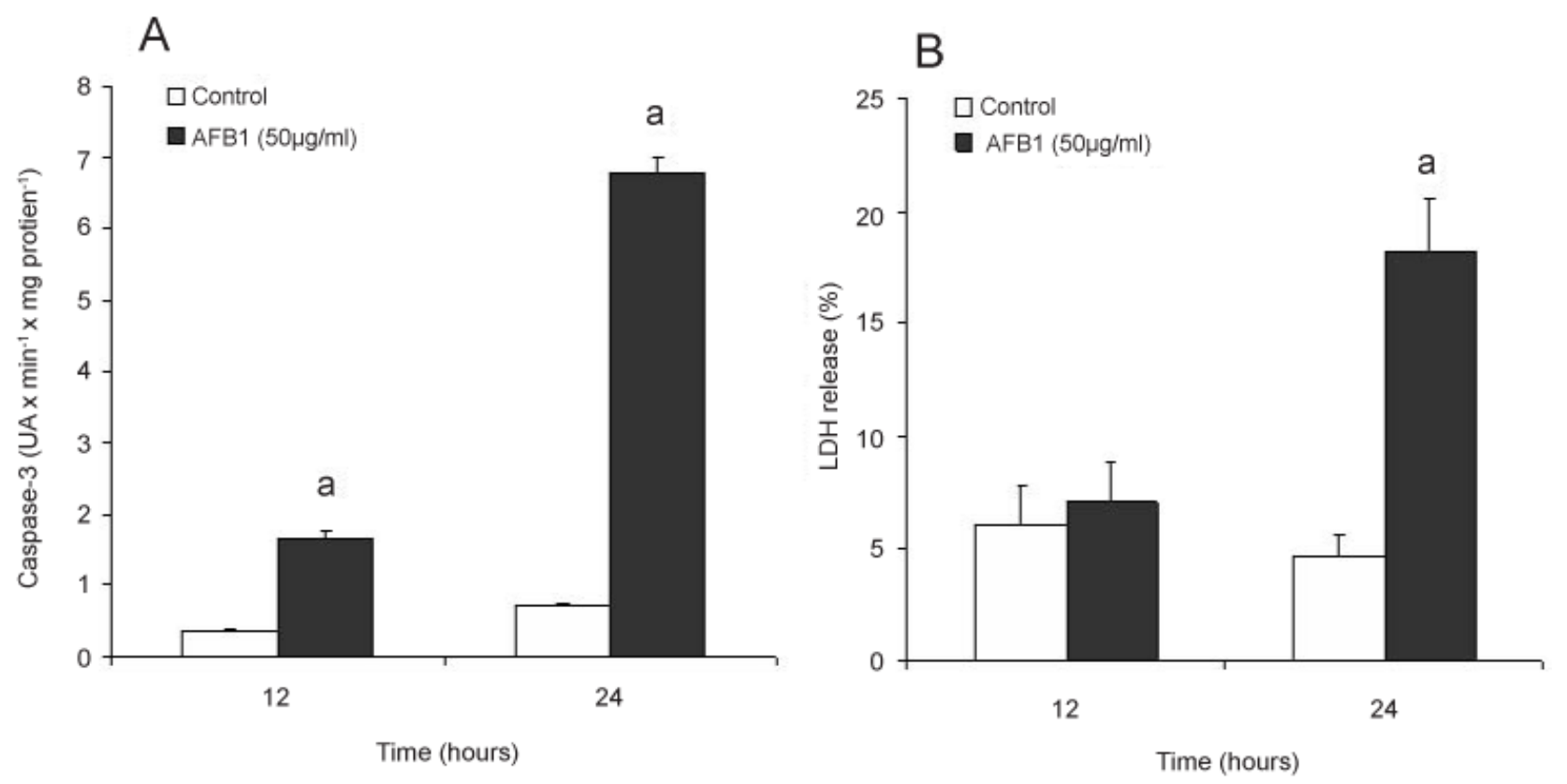

Figure 1: Effects of Aflatoxin $\mathrm{B}_{1}(\mathrm{AFB} 1)$ on apoptosis $(\mathrm{A})$ and necrosis $(\mathrm{B})$ in hepatoma cancer cells. Apoptosis and necrosis were measured by caspase-3 activity and LDH release in HepG2 cells, respectively. The groups with "a" were significantly different vs. the corresponding control group. The groups with " $\mathrm{b}$ " were significantly different vs. the corresponding group without $\mathrm{AFB}_{1}$.

\section{Effects of extracts in cell death, proliferation and DNA damage in AFB1-treated HepG2}

AFB1 increased caspase- 3 activity (Figure 1A) and LDH (Figure 1B) in HepG2 cells $(\mathrm{p} \leq 0.05)$. Oleuropein and Hydroxityrosol reduced cell necrosis (Figure $2 \mathrm{~A}$ and $2 \mathrm{C}$ ) and DNA damage (Figure 2B and 2D) in control and AFB1-treated hepatocytes $(\mathrm{p} \leq 0.05)$. However, the corresponding containing extracts such as olive leaves and olive oil mill waste extracts increased $\mathrm{LDH}$ release (Figures $3 \mathrm{~A}$ and $3 \mathrm{~B}$, respectively) and DNA damage (Figure $4 \mathrm{~A}$ and $4 \mathrm{~B}$, respectively) in hepatoma cells. Interestingly, this effect of olive leaves and olive oil mill waste extracts was related to arrest of cell proliferation at 24 hours in control and AFB1-treated HepG2 cells (Figures 5A and 5B) (p $\leq$ $0.05)$.

\section{Effects of natural extracts on the expression of p53 and c-Src oncoprotein in HepG2}

The administration of AFB1 increased the expression of p53 in nuclear fraction from HepG2 cells (Figure 6). AFB1-containing samples did not show p21 and p27 expression in HepG2 cells (data not shown). The administration of olive leaves (Figure 6A) and olive oil mill waste (Figure 6B) extracts reduced specially at their highest concentration p53 expression in control and AFB-treated HepG2 cells. c-Src is an oncoprotein with tyrosine kinase activity which exerts a relevant role in cell proliferation. The phosphorylation in Tyr416 and Tyr527 residues acts as a negative and positive regulator of the kinase activity. Tyr416 phosphorylation of c-Src was not detected in control and AFB1-treated HepG2 cells (data not shown). AFB1 increased the expression of total c-Src with a remarkable reduction of Tyr527 phosphorylation at 12 hours in HepG2 cells (Figure 7). The administration of natural extracts counteracted the effect of AFB1 on c-Src total levels and increased its Tyr527 phosphorylation (Figure 7).

\section{Discussion}

Many vegetable foods in Mediterranean diet contain substances possessing anticancer properties [51]. Epidemiological studies performed in different countries (Spain, Greece and Italy) have shown that the consumption of olive oil reduces the estimated relative risk of breast cancer [52-54]. Epidemiological studies have reported the strong correlation between the intake of olive oil and colon [55] or prostate [56] cancer. However, few experimental reports have demonstrated the antitumoral mechanism of olive-derived compounds. It has been recently shown that olive oil prevents the development of azoxymethane-induced aberrant crypt foci and colon carcinomas in rats [57].

Several phenolic compounds from olive, such as oil, leaves, fruits and waste processing may play a role in cancer protection. In this sense, hydroxytyrosol [3,4-dyhydroxyphenylethanol (3,4-DHPEA)], an ortho-diphenol derived from the hydrolysis of oleuropein, recently received particular attention because it may inhibit both initiation and promotion steps of carcinogenesis in vitro. The present study has shown that olive leaves extracts and olive mill waste, that contains oleuropein and hydroxytyrosol respectively, are able to increase DNA damage, reduce cell proliferation and promote cell death of hepatoma cells. 
Citation: Ranchal I, de Castro ML, Muntané J (2014) Olive Leaves and Mill Waste Exert Anti-Tumoral Properties in Hepatoma Cell Line. J

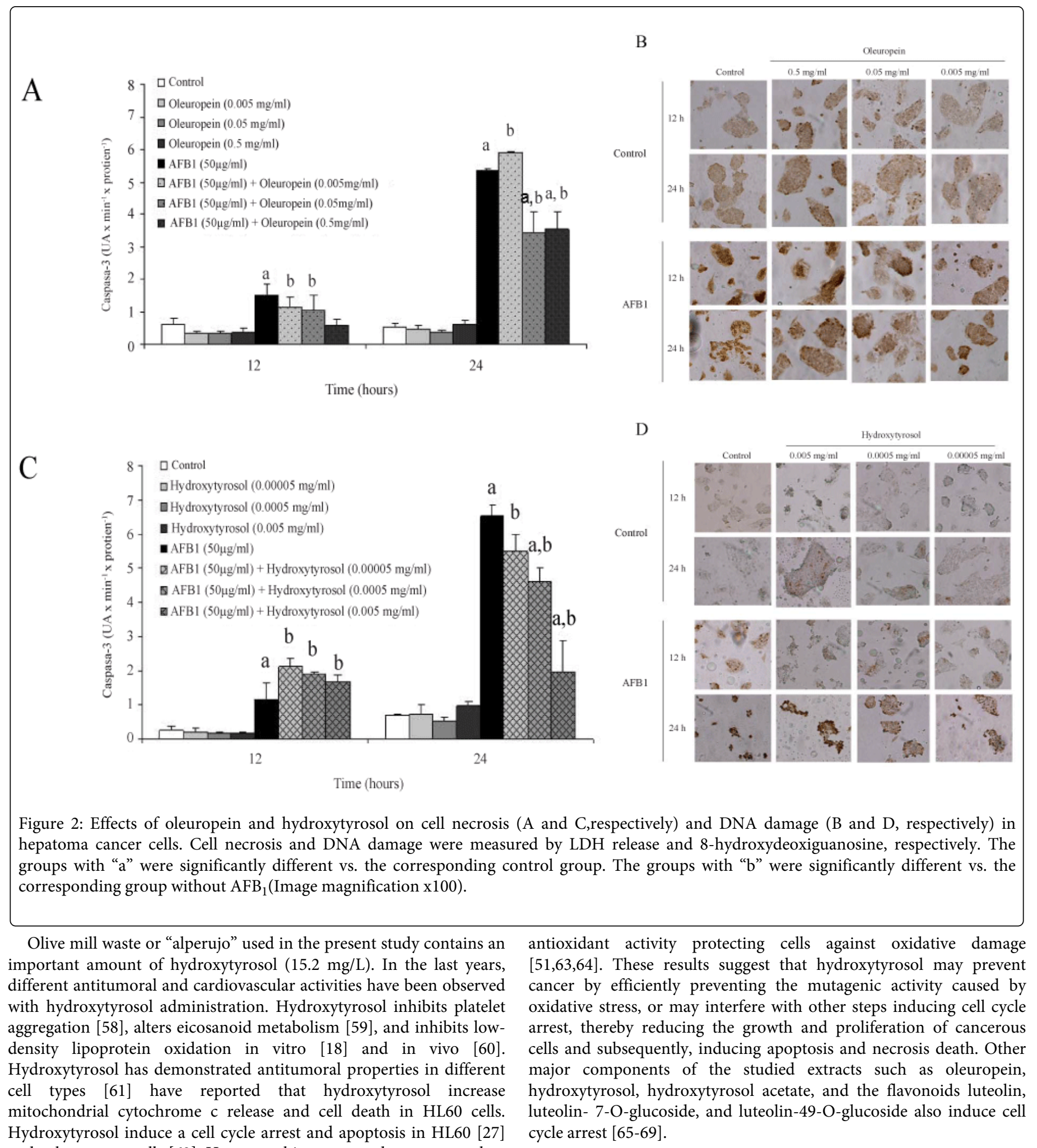

and colon cancer cells [62]. However, this compound possesses a clear 
Citation: Ranchal I, de Castro ML, Muntané J (2014) Olive Leaves and Mill Waste Exert Anti-Tumoral Properties in Hepatoma Cell Line. J
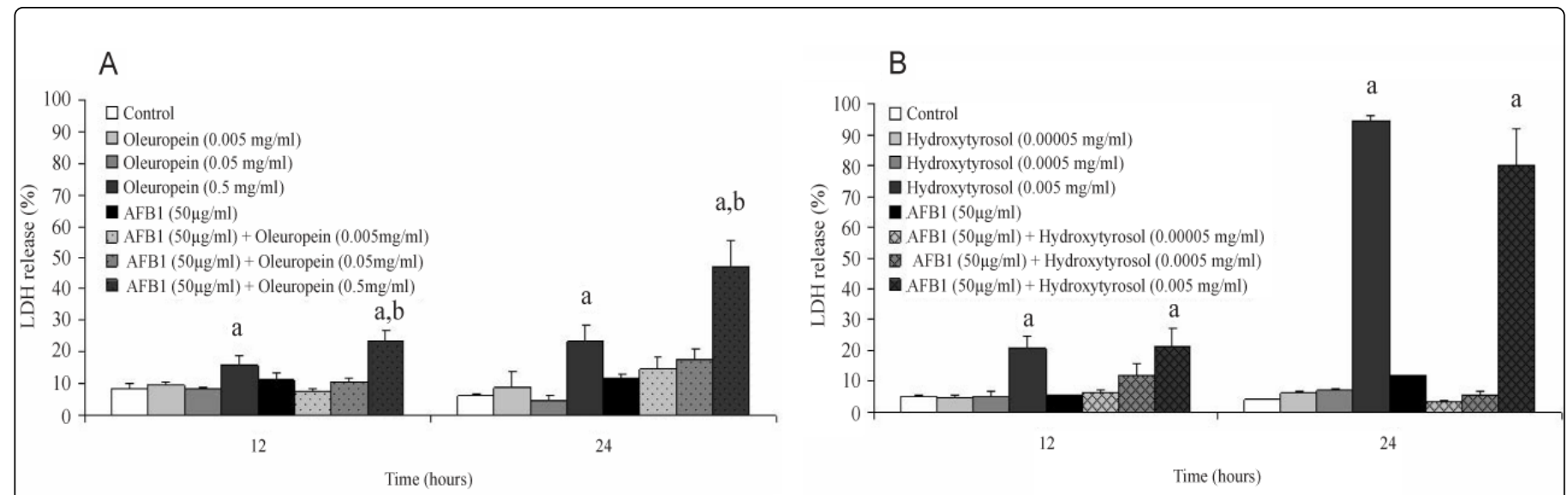

Figure 3: Effects of olive leaves (A) and olive oil mill waste (B) extracts on cell necrosis in Aflatoxin $B_{1}$ (AFB1)-treated HepG2 cells. Cell necrosis was assessed by LDH release in HepG2. The groups with "a" were significantly different vs. the corresponding control group. The groups with " $\mathrm{b}$ " were significantly different vs. the corresponding group without $\mathrm{AFB}_{1}$

A
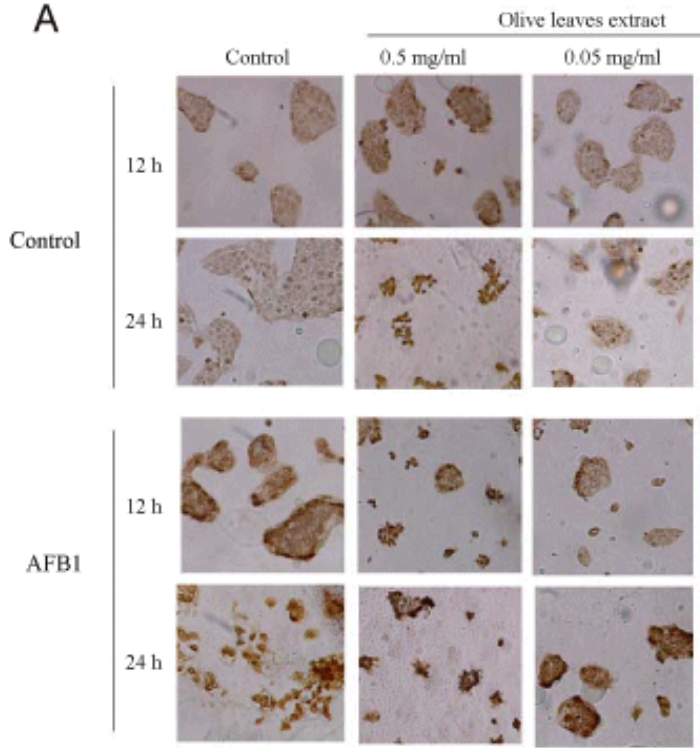

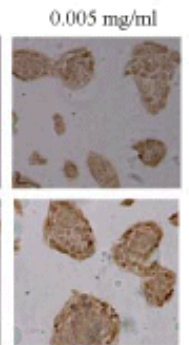

B

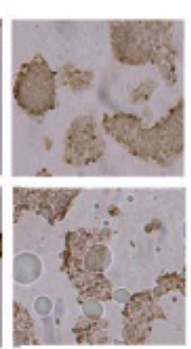

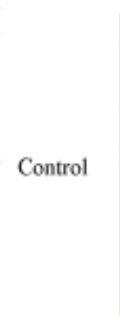
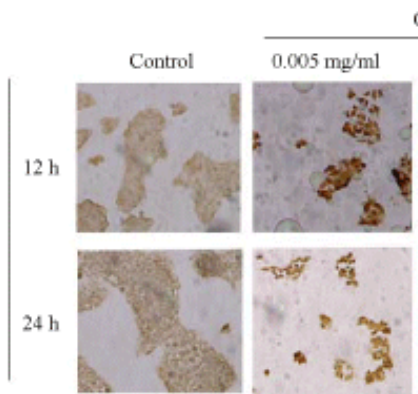

Olive oil mill waste
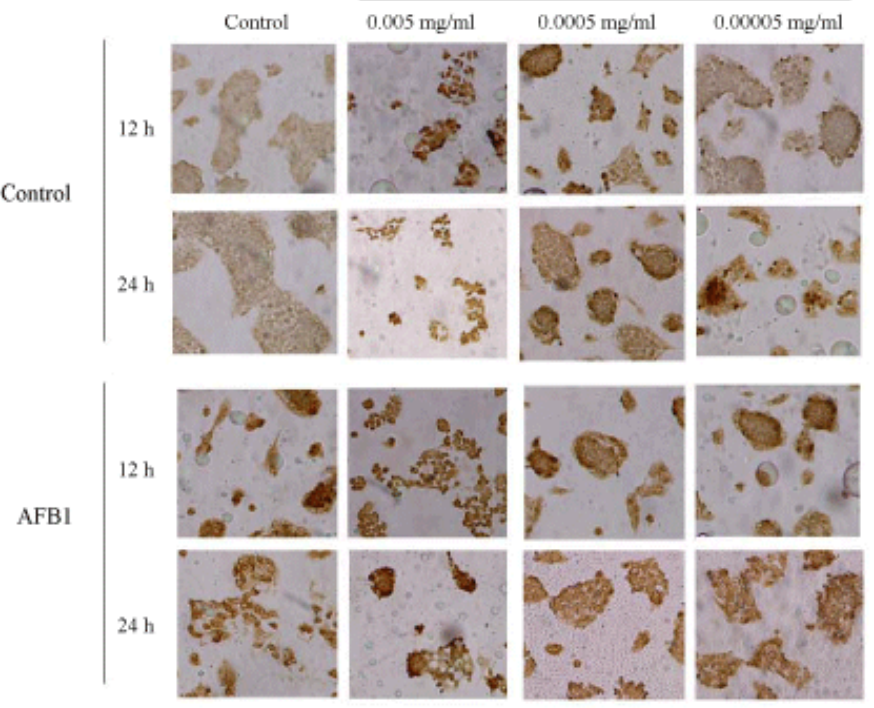

Figure 4: Effects of olive leaves (A) and olive oil mill waste (B) extracts on cell proliferation in Aflatoxin $\mathrm{B}_{1}$ (AFB1)-treated HepG2 cells. Cell proliferation was determined by BrdU incorporation in HepG2 cells. Samples were collected at 24 hours. The groups with "a" were significantly different vs. the corresponding control group. The groups with "b" were significantly different vs. the corresponding group without $\mathrm{AFB}_{1}$. 
Citation: Ranchal I, de Castro ML, Muntané J (2014) Olive Leaves and Mill Waste Exert Anti-Tumoral Properties in Hepatoma Cell Line. J

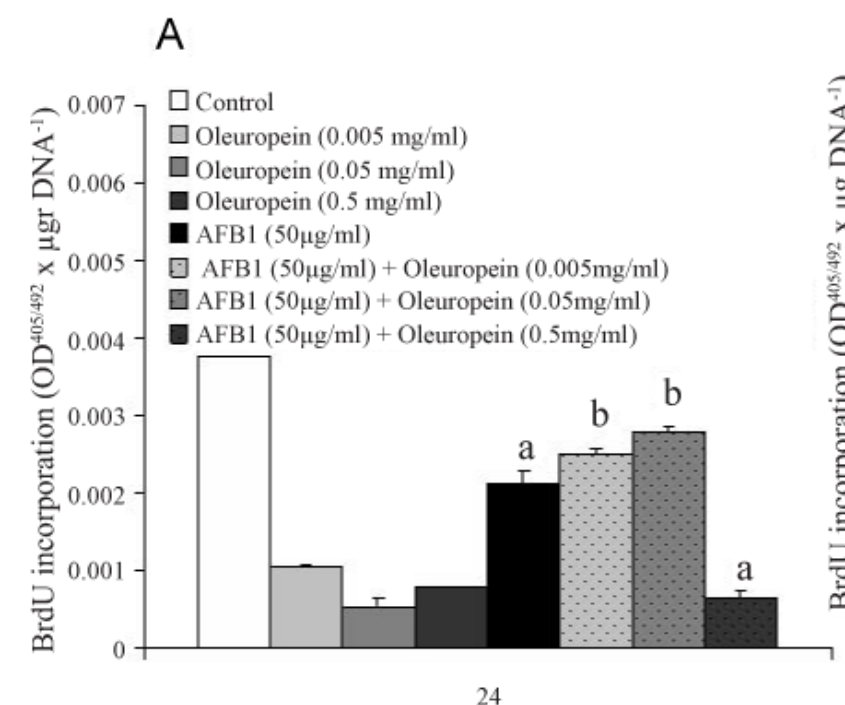

Time (hours)
B

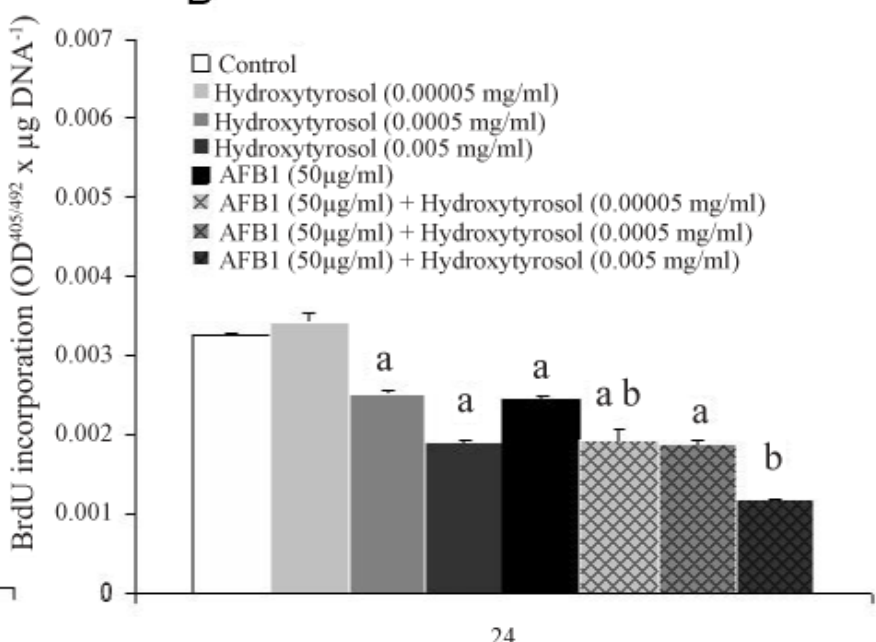

Time (hours)

Figure 5: Effects of olive leaves (A) and olive oil mill waste (B) extracts on DNA damage in Aflatoxin B1 (AFB1)-treated HepG2 cells. The images are representative of five different experiments.

\section{A}

p53

Protein load

Oleuropein $(0.5 \mu \mathrm{g} / \mathrm{ml})$

Oleuropein $(0.05 \mu \mathrm{g} / \mathrm{ml})$

Oleuropein $(0.005 \mu \mathrm{g} / \mathrm{ml})$

AFB1 $(50 \mu \mathrm{g} / \mathrm{ml})$

Time (hours)

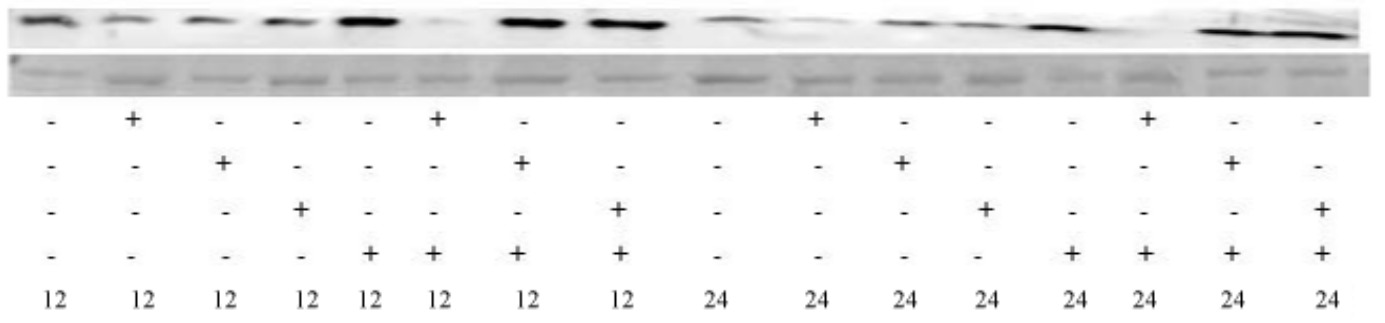

B

p53

Protein load

Hydroxytyroslo $(0.005 \mu \mathrm{g} / \mathrm{ml})$

Hydroxytyroslo $(0.0005 \mu \mathrm{g} / \mathrm{ml})$

Hydroxytyroslo $(0.00005 \mu \mathrm{g} / \mathrm{ml})$

AFBl $(50 \mu \mathrm{g} / \mathrm{ml})$

Time (hours)

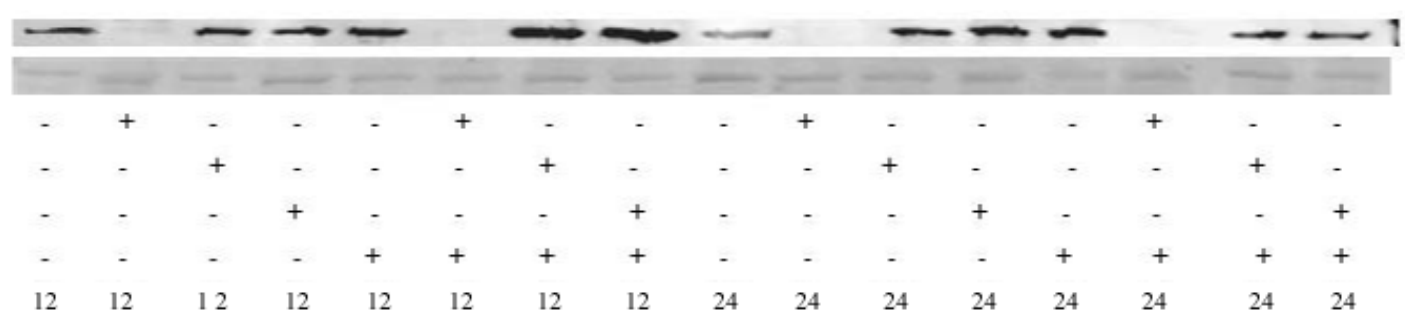

Figure 6: Effects of olive leaves (A) and olive oil mill waste (B) extracts on p53 protein expression in Aflatoxin B1 (AFB1)-treated HepG2 cells. p53 was assessed by western-blot analysis. The images are representative of five different experiments. 
Citation: Ranchal I, de Castro ML, Muntané J (2014) Olive Leaves and Mill Waste Exert Anti-Tumoral Properties in Hepatoma Cell Line. J

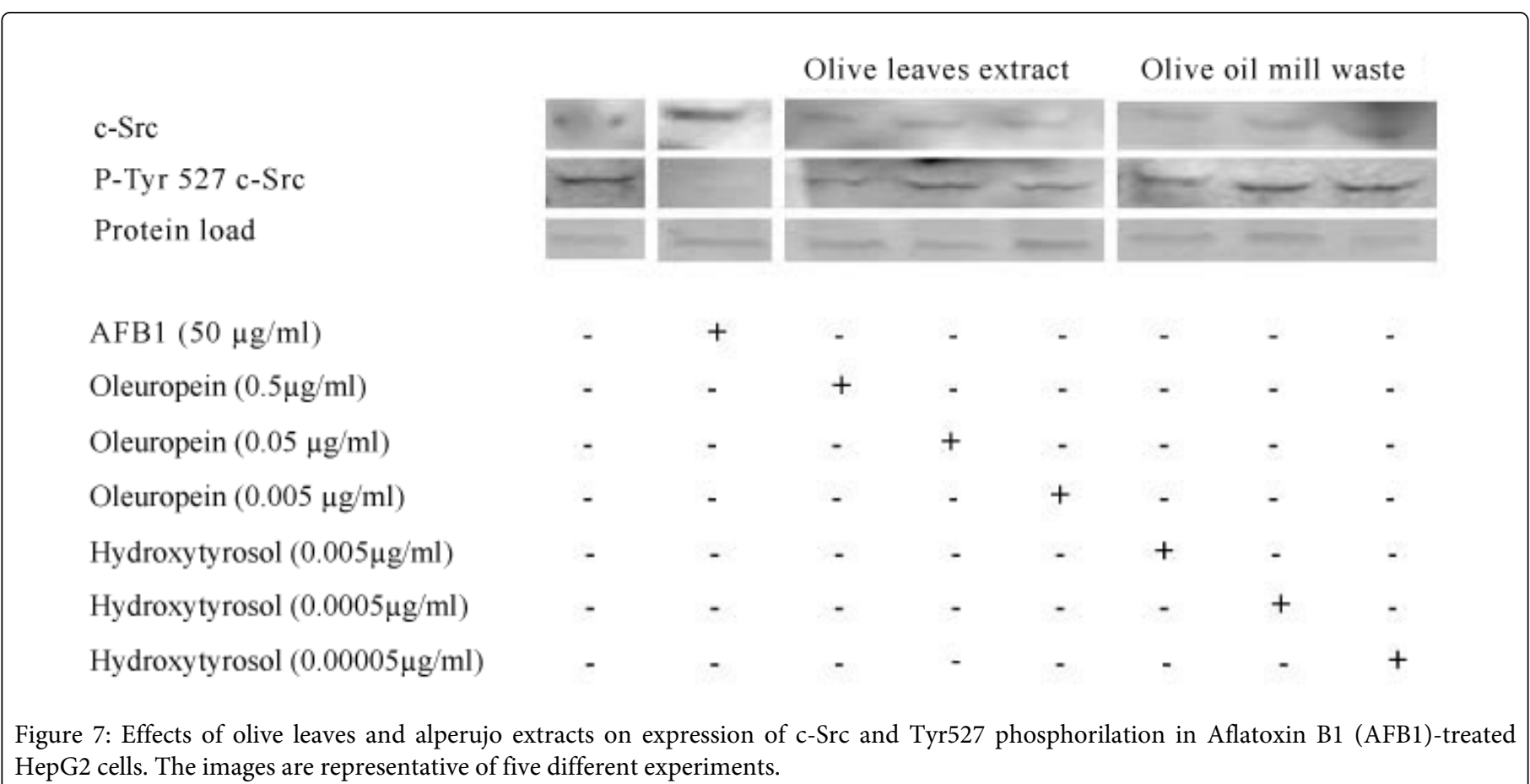

Several cell cycle regulators such as p27 and p53 have been identified as potential prognostic markers for the outcome of HCC [70-72]. AFB1 increased the expression of p53 in cells that were reduced by olive leaves and "alperujo" extracts. In many cases, the induction of $\mathrm{p} 21$ required the functional p53 tumor suppressor protein that is activated by DNA damage. In our conditions, we could not detect p21 and p27 in HepG2 cells (data not shown). The c-Src activity has strong association with advanced tumor stage and metastasis in different human carcinoma tissue [73,74]. c-Src affects cell proliferation and the metastatic properties of cancer cells $[75,76]$. In the present study we showed that the expression of c-Src is increased in AFB1-treated HepG2 cells. The activity of pp60c-Src is regulated through phosphorylation of different tyrosine residues. The phosphorylation of tyrosine residue 416 (Ptry416) has a positive regulatory effect on pp60c-Src kinase, whereas phosphorylation at the C-terminal tyrosine residue 527 (Ptyr527) acts as a negative regulator of the kinase activity [76]. The reduction of tyrosine 527 phosphorylation by AFB1 may exert an inducer effect on cell proliferation. In consequences, the reduction of $\mathrm{c}$-Src and relative increase of tyrosine residue 527 by the administration of olive leaves and "alperujo" extracts may be related to a reduction of cell proliferation in HepG2 cells.

In conclusion, the administration of olive leaves and olive oil mill extracts ("alperujo") is able to increase DNA damage, cell cycle arrest and apoptosis in hepatoma cell line. More studies should be done in order to identify if oleuropein, hydroxytyrosol or other components are responsible for this antitumoral effect.

\section{Acknowledgments}

This study has been supported in part by the Consejería de Innovación, Ciencia y Empresa (P06-FQM-01515) and Consejería de Salud (SAS 0103/2006) both from Junta de Andalucía (Spain). We thank Biomedical Research Network Center for Liver and Digestive
Diseases (CIBERehd) founded by "Carlos III" Health Institute for its support.

\section{Reference:}

1. WHO (2008) Global cancer rates to rise by $50 \%$ by 2020 .

2. European Association for the Study of the Liver1; European Organization for Research and Treatment of Cancer (2012) EASL-EORTC clinical practice guidelines: management of hepatocellular carcinoma. J Hepatol 56: 908-943.

3. Trichopoulou A, Lagiou P (1997) Healthy traditional Mediterranean diet: an expression of culture, history, and lifestyle. Nutr Rev 55: 383-389.

4. Trichopoulou A, Lagiou P, Kuper H, Trichopoulos D (2000) Cancer and Mediterranean dietary traditions. Cancer Epidemiol Biomarkers Prev 9: 869-873.

5. Simopoulos AP (2001) The Mediterranean diets: What is so special about the diet of Greece? The scientific evidence. J Nutr 131: 3065S-73S.

6. Simopoulos AP (2004) The traditional diet of Greece and cancer. Eur J Cancer Prev 13: 219-230.

7. 7.Perez-Jimenez F, Alvarez de Cienfuegos G, Badimon L, Barja G, Battino M, et al. (2005) International conference on the healthy effect of virgin olive oil. Eur J Clin Invest 35, 421-424.

8. Colomer R, Menéndez JA (2006) Mediterranean diet, olive oil and cancer. Clin Transl Oncol 8: 15-21.

9. Katan MB, Zock PL, Mensink RP (1995) Dietary oils, serum lipoproteins, and coronary heart disease. Am J Clin Nutr 61: 1368S-1373S.

10. Owen RW, Giacosa A, Hull WE, Haubner R, Spiegelhalder B, et al. (2000) The antioxidant/anticancer potential of phenolic compounds isolated from olive oil. Eur J Cancer 36: 1235-1247.

11. Montedoro GF, Servili M, Baldioli M, Selvaggini R, Miniati E, et al. (1993) Simple and hydrolyzable compounds in virgin olive oil. Spectroscopic characterization of the secoiridoids derivatives. J Agric Food Chem 41, 2228-2234. 
12. Servili M, Baldioli M, Selvaggini R, Macchioni A, Montedoro G (1999) Phenolic compounds of olive fruit: one- and two-dimensional nuclear magnetic resonance characterization of Nüzhenide and its distribution in the constitutive parts of fruit. J Agric Food Chem 47: 12-18.

13. Servili M, Selvaggini R, Taticchi A, Esposto S, Montedoro G (2003). Volatile compounds and phenolic composition of virgin olive oil: optimization of temperature and time of exposure of olive pastes to air contact during the mechanical extraction process. J Agric Food Chem 51:7980-7988

14. Litridou M, Linssen J, Schols H, Bergmans M, Posthumus M, et al. (1997) Phenolic compounds in virgin olive oils: fractionation by solid phase extraction and antioxidant activity assessment. J Sci Food Agric 74:169-174

15. Caponio F, Alloggio V, Gomes T (1999). Phenolic compounds of virgin olive oil: influence of paste preparation techniques. Food Chem 64: 203-209.

16. Papadopoulos G, Boskou D (1991) Antioxidantive effect of natural phenols on olive oil. J Am Oil Chem Soc 68: 669-671.

17. Baldioli M, Servili M, Perretti G, Montedoro GF (1996). Antioxidant activity of tocopherols and phenolic compounds of virgin olive oil. J Am Oil Chem Soc 73: 1589- 1593.

18. Grignaffini P, Roma P, Galli C, Catapano AL (1994) Protection of lowdensity lipoprotein from oxidation by 3,4-dihydroxyphenylethanol Lancet 343: 1296-1297.

19. Petroni A, Blasevich M, Salami M, Servili M, Montedoro GF, et al. (1994) A phenolic antioxidant extracted from olive oil inhibits platelet aggregation and arachidonic acid metabolism in vitro. World Rev Nutr Diet 75: 169-172.

20. Bonoli M, Bendini A, Cerretani L, Lercker G, Toschi TG (2004) Qualitative and semiquantitative analysis of phenolic compounds in extra virgin olive oils as a function of the ripening degree of olive fruits by different analytical techniques. J Agric Food Chem 52: 7026-7032.

21. Manna C, D'Angelo S, Migliardi V, Loffredi E, Mazzoni O, et al. (2002) Protective effect of the phenolic fraction from virgin olive oils against oxidative stress in human cells. J Agric Food Chem 50: 6521-6526.

22. de la Puerta R, Martínez Domínguez ME, Ruíz-Gutíerrez V, Flavill JA, Hoult JR (2001) Effects of virgin olive oil phenolics on scavenging of reactive nitrogen species and upon nitrergic neurotransmission. Life Sci 69: 1213-1222.

23. Hamdi HK, Castellon R (2003) ACE inhibition actively promotes cell survival by altering gene expression. Biochem Biophys Res Commun 310: 1227-1235.

24. Yang W, Bancroft L, Nicholas C, Lozonschi I, Augenlicht LH (2003) Targeted inactivation of p27kip1 is sufficient for large and small intestinal tumorigenesis in the mouse, which can be augmented by a Western-style high-risk diet. Cancer Res 63: 4990-4996.

25. Tuck KL, Hayball PJ (2002) Major phenolic compounds in olive oil: metabolism and health effects. J Nutr Biochem 13: 636-644.

26. Fabiani R, De Bartolomeo A, Rosignoli P, Servili M, Montedoro GF, et al. (2002) Cancer chemoprevention by hydroxytyrosol isolated from virgin olive oil through G1 cell cycle arrest and apoptosis. Eur J Cancer Prev 11: 351-358.

27. Fabiani R, De Bartolomeo A, Rosignoli P, Servili M, Selvaggini R, et al. (2006) Virgin olive oil phenols inhibit proliferation of human promyelocytic leukemia cells (HL60) by inducing apoptosis and differentiation. J Nutr 136: 614-619.

28. Hamdi HK, Castellon R (2005) Oleuropein, a non-toxic olive iridoid, is an anti-tumor agent and cytoskeleton disruptor. Biochem Biophys Res Commun 334: 769-778.
29. Jackson PE, Groopman JD (1999) Aflatoxin and liver cancer. Baillieres Best Pract Res Clin Gastroenterol 13: 545-555.

30. Garner RC, Miller EC, Miller JA (1972) Liver microsomal metabolism of aflatoxin B 1 to a reactive derivative toxic to Salmonella typhimurium TA 1530. Cancer Res 32: 2058-2066.

31. Hsu IC, Metcalf RA, Sun T, Welsh JA, Wang NJ, et al. (1991) Mutational hotspot in the p53 gene in human hepatocellular carcinomas. Nature 350: $427-428$.

32. Bressac B, Kew M, Wands J, Ozturk M (1991) Selective G to T mutations of p53 gene in hepatocellular carcinoma from southern Africa. Nature 350: 429-431.

33. Tashiro F, Morimura S, Hayashi K, Makino R, Kawamura H, et al. (1986) Expression of the c-Ha-ras and c-myc genes in aflatoxin B1-induced hepatocellular carcinomas. Biochem Biophys Res Commun 138: 858-864.

34. Sherr CJ (1996) Cancer cell cycles. Science 274: 1672-1677.

35. Dotto GP (2000) p21(WAF1/Cip1): more than a break to the cell cycle? Biochim Biophys Acta 1471: M43-56.

36. Yin L, Ghebranious N, Chakraborty S, Sheehan CE, Ilic Z, et al. (1998) Control of mouse hepatocyte proliferation and ploidy by p53 and p53ser246 mutation in vivo. Hepatology 27: 73-80.

37. Martin A (2001) Is tetralogy true? Lack of support for the "one-to-four rule". Mol Biol Evol 18: 89-93.

38. Biscardi JS, Tice DA, Parsons SJ (1999) c-Src, receptor tyrosine kinases, and human cancer. Adv Cancer Res 76: 61-119.

39. Irby RB, Yeatman TJ (2000) Role of Src expression and activation in human cancer. Oncogene 19: 5636-5642.

40. Mazurenko NN, Kogan EA, Zborovskaya IB, Kisseljov FL (1992) Expression of pp60c-src in human small cell and non-small cell lung carcinomas. Eur J Cancer 28: 372-377.

41. Verbeek BS, Vroom TM, Adriaansen-Slot SS, Ottenhoff-Kalff AE, Geertzema JG, et al. (1996) c-Src protein expression is increased in human breast cancer. An immunohistochemical and biochemical analysis. J Pathol 180: 383-388.

42. Irby R, Mao W, Coppola D, Jove R, Gamero A, et al. (1997) Overexpression of normal c-Src in poorly metastatic human colon cancer cells enhances primary tumor growth but not metastatic potential. Cell Growth Differ 8: 1287-1295.

43. Iravani S, Mao W, Fu L, Karl R, Yeatman T, et al. (1998) Elevated c-Src protein expression is an early event in colonic neoplasia. Lab Invest 78 365-371.

44. Lutz MP, Esser IB, Flossmann-Kast BB, Vogelmann R, Lührs H, et al (1998) Overexpression and activation of the tyrosine kinase Src in human pancreatic carcinoma. Biochem Biophys Res Commun 243: 503-508.

45. Masaki T, Okada M, Shiratori Y, Rengifo W, Matsumoto K, et al. (1998) pp60c-src activation in hepatocellular carcinoma of humans and LEC rats. Hepatology 27: 1257-1264.

46. Schreiber E, Matthias P, Müller MM, Schaffner W (1989) Rapid detection of octamer binding proteins with 'mini-extracts', prepared from a small number of cells. Nucleic Acids Res 17: 6419.

47. Japon-Lujan R, Luque de Castro (2006) Superheated liquid extraction of oleuropein and related biophenols from olive leaves. J Chromatogr A 1136:185-191

48. Japon-Lujan R , Luque de Castro (2007) Static-dynamic superheated liquid extraction of hydroxytyrosol and other biophenols from alperujo (a semisolid residue of the olive oil industry). J Agric Food Chem 55: 3629-3634.

49. Visioli F, Bellomo G, Galli C (1998) Free radical-scavenging properties of olive oil polyphenols. Biochem Biophys Res Commun 247: 60-64. 
50. Taffs RE, Redegeld FA, Sitkovsky MV (1991) Modulation of cytolytic T lymphocyte functions by an inhibitor of serine/threonine phosphatase, okadaic acid. Enhancement of cytolytic $\mathrm{T}$ lymphocyte-mediated cytotoxicity. J Immunol 147:722-728.

51. Martin-Moreno JM, Willett WC, Gorgojo L, Banegas JR, RodriguezArtalejo F, et al. (1994) Dietary fat, olive oil intake and breast cancer risk. Int J Cancer 58: 774-780.

52. la Vecchia C, Negri E, Franceschi S, Decarli A, Giacosa A, et al. (1995) Olive oil, other dietary fats, and the risk of breast cancer (Italy). Cancer Causes Control 6: 545-550.

53. Trichopoulou A, Katsouyanni K, Stuver S, Tzala L, Gnardellis C, et al. (1995) Consumption of olive oil and specific food groups in relation to breast cancer risk in Greece. J Natl Cancer Inst 87: 110-116.

54. Braga C, La Vecchia C, Franceschi S, Negri E, Parpinel M, et al. (1998) Olive oil, other seasoning fats, and the risk of colorectal carcinoma. Cancer 82: 448-453.

55. Tzonou A, Signorello LB, Lagiou P, Wuu J, Trichopoulos D, et al. (1999) Diet and cancer of the prostate: a case-control study in Greece. Int J Cancer 80: 704-708.

56. Bartolí R, Fernández-Bañares F, Navarro E, Castellà E, Mañé J, et al. (2000) Effect of olive oil on early and late events of colon carcinogenesis in rats: modulation of arachidonic acid metabolism and local prostaglandin E(2) synthesis. Gut 46: 191-199.

57. Petroni A, Blasevich M, Salami M, Papini N, Montedoro GF, et al. (1995) Inhibition of platelet aggregation and eicosanoid production by phenolic components of olive oil. Thromb Res 78: 151-160.

58. Petroni A, Blasevich M, Papini N, Salami M, Sala A, et al. (1997) Inhibition of leukocyte leukotriene B4 production by an olive oil-derived phenol identified by mass-spectrometry. Thromb Res 87: 315-322.

59. Wiseman SA, Mathot JN, de Fouw NJ, Tijburg LB (1996) Dietary nontocopherol antioxidants present in extra virgin olive oil increase the resistance of low density lipoproteins to oxidation in rabbits. Atherosclerosis 120: 15-23.

60. Ragione FD, Cucciolla V, Borriello A, Pietra VD, Pontoni G, et al. (2000) Hydroxytyrosol, a natural molecule occurring in olive oil, induces cytochrome c-dependent apoptosis. Biochem Biophys Res Commun 278: 733-739.

61. Guichard C, Pedruzzi E, Fay M, Marie JC, Braut-Boucher F, et al. (2006) Dihydroxyphenylethanol induces apoptosis by activating serine/ threonine protein phosphatase $\mathrm{PP} 2 \mathrm{~A}$ and promotes the endoplasmic reticulum stress response in human colon carcinoma cells. Carcinogenesis 27:1812-1827.

62. Manna C, Galletti P, Cucciolla V, Moltedo O, Leone A, et al. (1997) The protective effect of the olive oil polyphenol (3,4-dihydroxyphenyl)- ethanol counteracts reactive oxygen metabolite-induced cytotoxicity in Caco-2 cells. J Nutr 127: 286-292.

63. Manna C, Galletti P, Cucciolla V, Montedoro G, Zappia V (1999) Olive oil hydroxytyrosol protects human erythrocytes against oxidative damages. J Nutr Biochem 10: 159-165.

64. LoaJ, Chow P, Zhang k (2009) Studies of structure-activity relationship on plant polyphenol-induced suppression of human liver cancer cells. Cancer Chemother Pharmacol 63, 1007-1016.

65. Lu QY, Arteaga JR, Zhang Q, Huerta S, Go VL, et al. (2005) Inhibition of prostate cancer cell growth by an avocado extract: role of lipid-soluble bioactive substances. J Nutr Biochem 16: 23-30.

66. Plaumann B, Fritsche M, Rimpler H, Brandner G, Hess RD (1996) Flavonoids activate wild-type p53. Oncogene 13: 1605-1614.

67. Wang W, VanAlstyne PC, Irons KA, Chen S, Stewart JW, et al. (2004) Individual and interactive effects of apigenin analogs on G2/M cell-cycle arrest in human colon carcinoma cell lines. Nutr Cancer 48: 106-114.

68. Zhang Q, Zhao XH, Wang ZJ (2009) Cytotoxicity of flavones and flavonols to a human esophageal squamous cell carcinoma cell line (KYSE-510) by induction of G2/M arrest and apoptosis. Toxicol In Vitro 23, 797-807.

69. Tanaka N, Chiba T, Matsuzaki Y, Osuga T, Aikawa T, et al. (1993) High prevalence of hepatitis B and $\mathrm{C}$ viral markers in Japanese patients with hepatocellular carcinoma. Gastroenterol Jpn 28: 547-553.

70. Tannapfel A, Grund D, Katalinic A, Uhlmann D, Köckerling F, et al. (2000) Decreased expression of p27 protein is associated with advanced tumor stage in hepatocellular carcinoma. Int J Cancer 89: 350-355.

71. Ito Y, Matsuura N, Sakon M, Miyoshi E, Noda K, et al. (1999) Expression and prognostic roles of the G1-S modulators in hepatocellular carcinoma: p27 independently predicts the recurrence. Hepatology 30: 90-99.

72. Talamonti MS, Roh MS, Curley SA, Gallick GE (1993) Increase in activity and level of pp60c-src in progressive stages of human colorectal cancer. J Clin Invest 91: 53-60.

73. Mao W, Irby R, Coppola D, Fu L, Wloch M, et al. (1997) Activation of cSrc by receptor tyrosine kinases in human colon cancer cells with high metastatic potential. Oncogene 15: 3083-3090.

74. Sheppard D (2000) In vivo functions of integrins: lessons from null mutations in mice. Matrix Biol 19: 203-209.

75. Noritake H, Miyamori H, Goto C, Seiki M, Sato H (1999) Overexpression of tissue inhibitor of matrix metalloproteinases-1 (TIMP-1) in metastatic MDCK cells transformed by v-src. Clin Exp Metastasis 17: 105-110.

76. Cooper JA, Gould KL, Cartwright CA, Hunter T (1986) Tyr527 is phosphorylated in pp60c-src: implications for regulation. Science 231: 1431-1434. 